\title{
Management of Psoriasis (Kitibha-Kushtha) Through Classical Vamana Karma Followed by Internal Medicine : A Case Series
}

\author{
${ }^{1}$ Dr. Govind Narayan , ${ }^{2}$ Dr .Amrita Bhattarai , ${ }^{3}$ Dr. Gopesh Mangal \\ ${ }^{1}$ MD Scholar, Department of Panchkarma, National Institute Of Ayurveda, Jaipur, India. \\ ${ }^{2}$ MD Scholar, Department of Panchkarma, National Institute Of Ayurveda, Jaipur, India. \\ ${ }^{3}$ Assistant Professor and Head (I/C), Department of Panchkarma, National Institute Of Ayurveda Jaipur, \\ India.
}

\begin{abstract}
Psoriasis is a chronic, non-communicable, painful, disfiguring and disabling disease for which there is no cure and with great negative impact on patient's quality of life. The reported prevalence of psoriasis in countries ranges between $0.09 \%$ and $11.4 \%$, making psoriasis a serious global problem. Psoriasis causes great physical, emotional, and social burden, in general is often significantly impaired. Treatment of psoriasis is still based on controlling the symptoms. Kitibha-Kushtha is one of the skin disorders described under the heading of Ksudrakushtha. It is Vata- Kapha predominant disorder with the features like Shyavavarna, Kina, Kharasparsh, Kathina, Sarava, Kandu. Psoriasis patients complain about extensive itching, dryness which is characteristic feature of Kitibha-Kushtha, and shows Vata-Kapha predominance of disease. In this study 3 patients of Kitibha-Kushtha were taken. All 3 patients were treated with Classical Vamana Karma (therapeutic emesis) followed by Aragwadha Patra Lepa along with Shamana Yoga Lelitaka (Gandhaka) at dose of 500mg twice daily with honey in empty stomach.The result was encouraging in all the 3 cases of Psoriasis.
\end{abstract}

Key words:-Psoriasis, Kitibha-Kushtha, Vata- Kapha, Vamana Karma.

\section{INTRODUCTION}

Dermatological conditions are of great issues, because of their direct impact on patients physical, psychological, emotional \& socio-economic aspects. Among various dermatological conditions psoriasis is considered one of the dreadful conditions. It is an autoimmune, non-contagious inflammatory skin disease characterized by recurring reddish patches covered with silvery scales. It can occur in any age, and is most common in the age group 50-69 ${ }^{1}$ The reported prevalence of psoriasis in countries ranges between $0.09 \%{ }^{2}$ to $11.4 \%^{3}$, making psoriasis a serious global problem. Its prevalence rate ranges from $0.44 \%$ to $2.8 \%$ in Indian population ${ }^{4}$.

Treatment of psoriasis is still based on controlling the symptoms. So far there is no therapy that would give hope for a complete cure of psoriasis. So, psoriasis still stands as a challenge to different medical systems. Additionally care for patients with psoriasis requires not only treating skin lesions and joints involvement, but it is also very important to identify and manage common comorbidity that already exists or may develop ,including cardiovascular and metabolic diseses as well as psychogical conditions. So it is need of time to find safe, effective treatment to psoriasis. Kushtha is described since time of Veda. In Ayurveda all dermatological conditions are grouped under broad term Kushtha which again have two divisions Mahakushtha and Kshudrakushtha on the basis of their symptoms, severity \& involvement of deeper Dhatu. Psoriasis has a wide range of presentation from just a single spot to involvement of whole body. Based on resemblance of symptoms and analysis of the nature of disease. Psoriasis can be correlated with KitibhaKushtha.

Kitibha-Kushtha is one of the skin disorders described under the heading of Ksudrakushtha. It is VataKapha predominant disorder with the features like Shyavavarna, Kina, Kharasparsh, Kathina, Sarava, $K a n d u^{5}$ Psoriasis patients complain about extensive itching, dryness which is characteristic feature of 
Kitibha-Kushtha. The features of Kitibha-Kushtha are similar to its modern counterpart psoriasis as it has erythematous, blackish scaly macule/papule/plaque, desquamation which is demarcated and indurated. In Kitibha the lesions are Shyavavarna, Kina, Kharasparsha, Ugrakandu and Sravi (exudation). However, in case of chronic condition of Psoriasis the lesions are found blackish with severe itching. Shyavavarna is also not characteristic features of Psoriasis but it may found in the form of hyper pigmented patch after medication. The treatment modalities available for psoriasis are not very satisfactory and have many adverse effects, so there is need of better treatment plan for the disease. The holistic approach of Ayurvedic management of diseases is key for present scenario. On the other hand the disease is described in detail in Ayurveda including its stepwise management which aims at correction of basic cause and reverse the pathology through the holistic approach.

Ayurveda treatment includes Shodhana (purification), Shamana (palliative medicine), Nidana Parivarjana (abstaining from etiology) and Rasayana (Rejuvination). While mentioning about treatment of Kushtha, Acharya has specifically emphasized on Shodhana Chikitsa because of its repeated relapse. Due to Sodhana (bio-purification) vitiated Dosha are eliminated, the power of digestion and metabolism is enhanced, diseases are cured, normal health is restored, sense organs, mind, intelligence and complexion become clear, and person is not affected by old age and lives long without any disease 6 . Vamana is considered the best line of treatment for Kaphaja disorders ${ }^{7}$.Kushtha is a Raktapradoshaja Vikara \& Kitibha-Kushtha is Vata-Kapha predominant type of Kushtha. So Vamana Karma ultimately pacifies the basic causative factors (Dosha \& Shithila Dhatu) which result into early recovery. All the 3 cases that are going to be described here are at chronic stage of Psoriasis. Proper administration of drugs after Sodhana therapy helps in management of psoriasis and prolong the duration of its relapse.

\section{MATERIAL AND METHODS}

The patients presented with signs and symptoms of Psoriasis along with clinically diagnosed \& confirmed cases of Psoriasis from OPD \& IPD section of National Institute of Ayurveda, Jaipur were taken for study.

\section{PRESENTING COMPLAINTS AND CLINICAL FINDINGS}

Case 1: A 27 years old male patient came to Panchkarma OPD at National Institute of Ayurveda Jaipur, India with complaint of blackish, scaly patches on whole body especially in neck along with itching in different part of body. As per patient, he was asymptomatic before 5 years and then he slowly developed itching and scaling over neck and gradually the itching and scaly patches appeared over whole body. Patient went for different Allopathic treatments, did not get relief so came for Ayurveda treatment. No personal and family history of any major systemic illness was present. No history of any addiction was found. However stress regarding the disease was present.

On physical examinations patient was found afebrile with Blood Pressure - 110/80 mm of $\mathrm{Hg}$, Pulse rate 72/minute, R.R. - 20/minute. On Systemic examination no abnormality was found in respiratory, cardiovascular and central nervous system activity. On skin examination lesions were visible rough,blackish silvery shiny and different shaped patches with well demarcated borders. Auspitz Sign was positive. The patient was Pitta Kapha Prakruti, having Madyam Koshtha and Madyam Bala. Rasavaha, Raktavaha, Medovaha, Purishavaha and Swedovaha Srotodushti Lakshanas were observed.

Case 2: A 42 years old female patient came to Panchkarma OPD at National Institute of Ayurveda Jaipur, India with complaint of Blakish Scaly Patches and itching at right lower limb, along with swelling. As per patient, she was asymptomatic 3 years before and then she developed itching in anterior aspect of right lower limb, after some days Slivery Patches began to develop. In few months there was swelling in right lower limb. Patient tried different Allopathic treatments but did not get proper relief in last 3 years so came for Ayurveda Treatment. No personal and family history of any major systemic illness was present. But stress regarding the disease was present.

On physical examinations patient was found afebrile with Blood pressure - 120/80 mm of $\mathrm{Hg}$, Pulse rate 76/minute, R.R. - 22/minute. On Systemic examination no abnormality was found in respiratory, cardiovascular and central nervous system activity. On skin examination of right lower limb, lesions were visible rough, blackish, some were slivery shiny and different shaped patches with well demarcated borders. Auspitz Sign was positive. There was swelling in the right leg. The patient was Vata Kapha Prakruti, having 
${ }^{1}$ Dr. Govind Narayan , International Journal of Ayurvedic \& Herbal Medicine 8(3) May.-June. 2018 (3265-3270)

Madyam Koshtha and Madyam Bala. Rasavaha, Raktavaha, Medovaha, Purishavaha and Swedovaha Srotodushti Lakshanas were observed.

Case 3: A 21 years old male patient came to Panchkarma OPD at National Institute of Ayurveda Jaipur, India with complaint of Blackish Scaly Patches and Itching at different parts of the body. As per patient, he was asymptomatic before 5 years before and then he developed itching and scaling over elbow and gradually the itching and scaly patches appeared over limbs and trunk. Patient did not get proper relief in last 5 years from different Allopathic treatments so came for Ayurveda Treatment. No history of any addiction was found. No personal and family history of any major systemic illness was present. Stress regarding the disease was present; he was not able to sleep properly during night due to stress.

On physical examinations patient was found afebrile with Blood pressure - 110/70 mm of $\mathrm{Hg}$, Pulse rate 74/minute, R.R. - 22/minute. On Systemic examination no abnormality was found in respiratory, cardiovascular and central nervous system activity. On skin examination lesions were visible rough ,blackish and some were silvery shiny,different shaped patches with well demarcated border.) On examination Auspitz Sign was positive. The patient was of Vata Kapha Prakruti, having Madyam Koshtha and Madyam Bala. Rasavaha, Raktavaha, Medovaha, Purishavaha and Swedovaha Srotodushti Lakshanas were observed.

\section{Diagnosis and treatment :}

All three patients were diagnosed as Psoriasis(Kitiba Kustha), and management was done accordingly as follows.

\section{Therapeutic intervention}

All three patients were admitted having I.P.D. NO.7541, 4440 and 3410 respectively. All 3 patients were treated with Classical Vamana Karma (therapeutic emesis) followed by Aragwadha Patra Lepa along with Shamana Yoga Lelitaka (Gandhaka) at dose of 500mg twice daily with honey early in the morning in empty stomach. Pathya Aahar (dietetic regimen) was explained to all of them.

\section{Vamana Karma}

Pre- Procedure: Deepana Pachana done with Panchakola Churna 3gm twice a day with lukewarm water for 3 days till Samyak Pachana Lakshyanas. Administration of Shodhananga Snehapana was done with

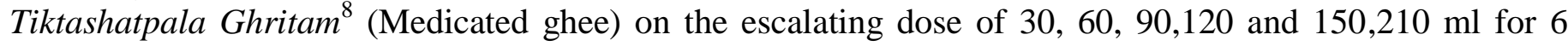
days everyday at 7 am in the morning. Patients were advised to strictly follow regimens advised on Snehapana (internal oleation).Samyak Snigdhata Lakshanas (signs of proper oleation) were observed and then Sarvanga Abhyanga (whole body Ayurveda massage) with Dashamula Taila (Dashamula medicated oil) and Baspa Swedana (Steam sudation) with Dasamula decoction was done on next day morning empty stomach at 9 am. Kaphautkleshakara food was given for diet in the evening. There was no any complications observed in all three patients during pre-procedure.

Procedure: Traditional Vamak yoga ${ }^{9}$ (combination of with Kutajbeeja, Madanphla, Mdhuka, Patola, total of $5 \mathrm{gm}$ was taken and it was mixed with Nimba Patra Rasa Kwath) was used. Vamanopaga Kashaya Yastimadhu, Milk, lavanodaka were used. Observations for Samyak Suddhi Lakshanas (signs of proper purification) were made. 9 Vegas with Pittaantaki Pravar Suddhi was observed first two patients while in case of third patient 7 Vegas with Madhyam Suddhi was observed, Patients were haemodynamically stable within the procedure and no sign of dehydration was observed after Vamana.

Post-procedure: Classical Samsarjana Krama Peyadi Krama (sequence) with 2 Annakala was advised for 7 days. On 8 th day after Vamana normal diet was adviced. Aragwadha Patra Lepa, was given for local application in affected part early in the morning in presence of sunlight, once daily. Suddha Gandhaka 500 mg twice with honey in empty stomach was given to patient after Samsarjana Krama.

\section{Follow up and outcomes}


${ }^{1}$ Dr. Govind Narayan , International Journal of Ayurvedic \& Herbal Medicine 8(3) May.-June. 2018 (3265-3270)

Table 1.Subjective parameter

\begin{tabular}{|c|c|c|c|c|c|c|}
\hline & \multicolumn{2}{|c|}{ Patient $1^{\text {st }}$} & \multicolumn{2}{|c|}{ Patient $2^{\text {nd }}$} & \multicolumn{2}{|c|}{ Patient $3^{\text {rd }}$} \\
\hline Signs and symptoms & BT & AT & BT & AT & BT & AT \\
\hline $\begin{array}{c}\text { Shyavavarna (Blackish } \\
\text { discolouration) }\end{array}$ & 3 & 1 & 2 & 1 & 3 & 1 \\
\hline Kina (Scaling) & 2 & $\mathbf{1}$ & 2 & 1 & 3 & 2 \\
\hline Kharasparsha (Dryness) & 3 & 1 & 3 & 2 & 3 & 3 \\
\hline Kathina (Hardness) & 2 & 1 & 2 & 1 & 3 & 1 \\
\hline Srava (Oozing) & 2 & 1 & 3 & $\mathbf{1}$ & 2 & 1 \\
\hline Kandu (Itching) & 3 & 1 & 3 & 1 & 3 & 1 \\
\hline
\end{tabular}

Table 2: Objective Parameters

\begin{tabular}{|c|c|c|c|c|c|c|}
\hline & \multicolumn{2}{|c|}{ Patient 1 $^{\text {st }}$} & \multicolumn{2}{c|}{ Patient 2 $^{\text {nd }}$} & \multicolumn{2}{c|}{ Patient 3 $^{\text {rd }}$} \\
\hline Signs & BT & AT & BT & AT & BT & AT \\
\hline Auspitz sign & Positive & Negative & Positive & Negative & Positive & Negative \\
\hline
\end{tabular}

After Vamana Karma there was marked improvement in signs and symptoms i.e in Shyavavarna (Blackish discolouration),Kandu(itching), Kharasparsha(roughness) and Sravi (exudation). Auspitz sign was negative. No any Vyapads (complications) during full course of Vamana Karma and during follow up was seen. On follow up after 1 month, patients were very happy and satisfied with the management. There was $75 \%$ relief in the previous symptoms.

\section{DISCUSSION}

According to Acharya Charaka, Kushtha is a Bahudosha condition and Kleda Pradhana Vikara. He also emphasized on the important of Sapta Dravya (because Saptadravyas are playing as Sannikrishta Hetus for Kushtha) i.e. Tridosha and Twaka, Rakta, Mamsa, Ambu. Whenever the Dosha Dushya Sammurshana occurs in Twak then Kushtha will be produced. ${ }^{10}$

Kitibha-Kushtha is Tridoshaja Vyadhi with predominance of Vata- Kapha. Repeated Shodhana Karma is indicated in Kustha due to involvement of Bahu Dosha. While undergoing through the pathogenesis of Kitibha-Kushtha there is mainly Rasa, Rakta and Mamsa Dhatu Dusti. Rasavaha, Raktavaha, Mamsavaha and Swedavaha Srotodushti are found in Kitibha-Kushtha. Angnimandya is the root cause of all the diseases, causing Aama \& Aamavisha formation,which is also seen in Kitiba Kustha. The Aamavisha spreads to whole body \& disturb the normal physiology of the Dhatu, thereby rendering them Shithila. The Dhatvagni is also deranged. Thus the Dhatu Shithilata further progresses. The three Dosha \& Poshaka Amsha of 4 Dushya reach the Shithila Dushya \& settle there to start the pathology in that tissue.

Considering the status of Dosha Dushya, Agni, Samprapti Vaishistyata and Vyadhi Lakshana, classical Vamana Karma was administered in the present clinical study. Due to Ushna and Laghu Guna (hot and light property) of Panchakola Churna used for Deepana and Pachana it helped in reducing the Aam Dosha and increasing Agni. There after pure Tiktashatpala Ghritam was given for the Snehapana. Snehpana reduced the burning sensation (Daha), lubricated the body and thus reduced dryness over the scales. The patches of psoriasis are dry \& scaly. The Tiktashatpala- Ghrita provides proper moisture to it,resulting in slowing of rapid turnover of epithelium. As dryness reduces some sort of soothing analgesic effect is experienced by the patient. It can be said that Tiktashatpala Ghritam reaches deep into the body tissues causing partial rejuvenation of cell organelles and smoothening of stagnated metabolic wastes and makes their elimination possible. Sarvanga Swedana done removed obstruction in Srotas (channels) and helped to bring Doshas from Sakha(periphery) to Koshtha by Srotoshodhaka (purification of channels) process and by the help of Sodhana - Vamana Karma Dosha are eliminated. 
Samshodhana therapy has its key strength in preventing relapse of disease. Acharya Charaka has specifically mentioned that there is a chance of recurrence of disease when treated with only Shamana therapy (internal medicine) but when Samshodhana is done there is no chance of recurrence or it is reduced significantly ${ }^{11}$ as recurrent relapse is the major problem for Psoriasis patients so the Vamana Karma was proved beneficial in preventing relapse.The drugs used during Vamana Karma such as Kutajbeeja, Madanphla, Madhuka, Patola, Nimba Patra Kwath are especially indicated in Kustha. All these drugs having Tikta Rasa, Kandughna \& Kusthagna property.

In our classical text detailed description of various single and compound preparations in the form of internal and external application are mentioned. Charaka has advised it with Tikta \& Kashaya Dravya after Shodhana. ${ }^{12}$ Samana Yoga: After completion of Vamana Karma, all three patients were given Suddha Gandhaka $^{13} 500 \mathrm{mg}$ twice daily in early morning with honey.Gandhaka(Lelitaka) has Amadoshahara, Deepana, Pachana, Dhatvagnivardhaka, Krimighna, Balya, Dadru-Garavisha-Kushtha, Kandu and Visarpahara properties.It was adviced as Dhatu Suddhikara and Rasayana. As per pharmacology Sulphar has antibacterial and anti fungal properties.

Aragwadha Patra Kalka Lepa ${ }^{14}$ was applied to the affected part early in the morning in presence of sunlight, once daily. Kalka was mixed with Takra and applied locally. Aragwadha is useful as a good laxative and anti- dermatosis drug. Due to its Sheeta Virya and Vata Pitta Shamaka properties it is very useful in skin diseases especially when applied locally. It is beneficial as it is Dahahara(subsides burning sensation), Vednasthapaka. It is useful in boils, wounds, ulcers, scabies, itchy and other skin infection, urticaria, leprocey, pruritis, blood impurities. Because of these properties of Aragwadha it is very effective in skin disorder. Also the anti-inflammatory activity of aqueous extract of leaves and fruits of Cassia fistula reported.

\section{CONCLUSION}

In all these 3 cases there was marked improvement in psoriasis. The combined treatment applied here as described in our classics, Sodhana and Samana along with local application of drug helped in proper management of Psoriasis (Kitiba-Kushtha).So Panchkarma procedure along with the internal medicines and healthy dietary and lifestyle regimen used after Sodhana (body purification) can provide a hope of ray to this current era for in management of Psoriasis.

\section{REFERENCES}

1. Institute for health Metrics and Evaluation(IHME).Global burden of Disease study 2010:Results by Cause 1990-2010.Seattle:IHME;2012.

2. Gibbs S.Skin disease and socioeconomic conditions in rural Africa:Tanzania.Int J Dermtol 1996;35(9):633-9.

3. Danielsen K,Olsen AO,Wilsegaard T,Furberg AS.Is the prevalence of psoriasis increasing?A 30-year follow - up of a population -based cohart.Br J Dermatol.2013;168:1303-10.

4. Dogra S, Yadav S. Psoriasis in India: prevalence and pattern. Indian $\mathrm{j}$ Dermatol Venereol Leprol.2013; 76(6):595-601.

5. Vaidhya Samrata Sri Satya Narayana Sastri(2013),Charak Samhita,Chikitsasthana, Chaukhamba Bharati Academy Varanasi,Chapter 7,Verse 22 page no 252

6. Vaidya Jadavji Trikamji Acharya(2013), Charaka Samhita, (Sutrasthana, Chapter 16,Verse 17-19), Reprint, Varanasi, Chaukambha Prakashan, page no 97.

7. Vaidya Jadavji Trikamji Acharya(2013), Charaka Samhita, (Sutrasthana, Chapter 25,Verse 40), Reprint, Varanasi, Chaukambha Prakashan, page no 132.

8. Vaidhya Samrata Sri Satya Narayana Sastri(2011),Charak Samhita,Chikitsasthana, Chaukhamba Bharati Academy Varanasi,Chapter 7,Verse 140-143, page no 269-270.

9. Vaidhya Samrata Sri Satya Narayana Sastri(2011),Charak Samhita,Chikitsasthana, Chaukhamba Bharati Academy Varanasi,Chapter 7,Verse 43-44, page no 255-256.

10. Vaidhya Samrata Sri Satya Narayana Sastri(2011),Charak Samhita,Chikitsasthana, Chaukhamba Bharati Academy Varanasi,Chapter 7,Verse 7-9, page no 248.

11. Ch.Su.16/20, Brahmanand Tripathi,volume I,Edition2013Chaukhamba publishing House,Varanasi.page323,ISBN:9789381484753(Vol I). 
${ }^{1}$ Dr. Govind Narayan , International Journal of Ayurvedic \& Herbal Medicine 8(3) May.-June. 2018 (3265-3270)

12. Vaidhya Samrata Sri Satya Narayana Sastri(2011),Charak Samhita,Chikitsasthana, Chaukhamba Bharati Academy Varanasi,Chapter 7,Verse 58, page no 258.

13. Vaidhya Samrata Sri Satya Narayana Sastri(2013), Charak Samhita,Chikitsasthana, Chaukhamba Bharati Academy Varanasi,Chapter 7,Verse 70 page no ....

14. Vaidhya Samrata Sri Satya Narayana Sastri(2013), Charak Samhita,Chikitsasthana, Chaukhamba Bharati Academy Varanasi,Chapter 7,Verse 96,page no 264.

\section{Photo Images}

Case 1st

BT

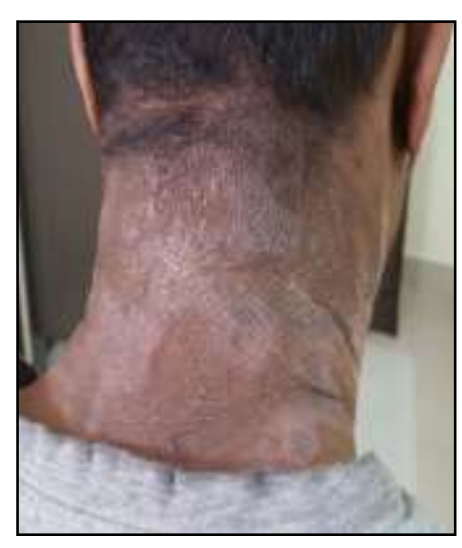

AT

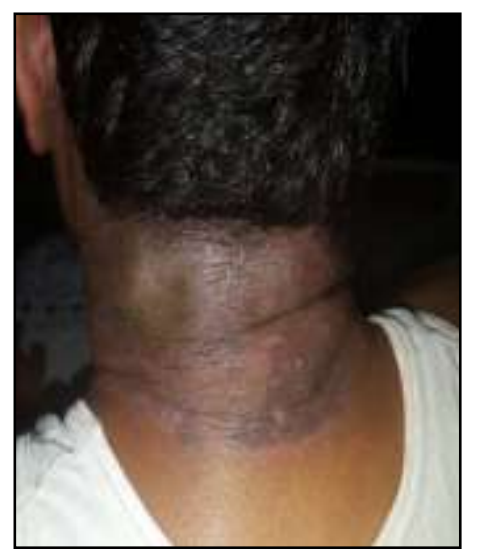

Case $2^{\text {nd }}$

BT

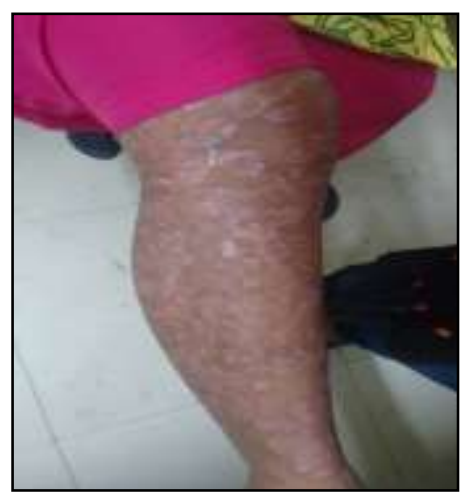

BT
AT

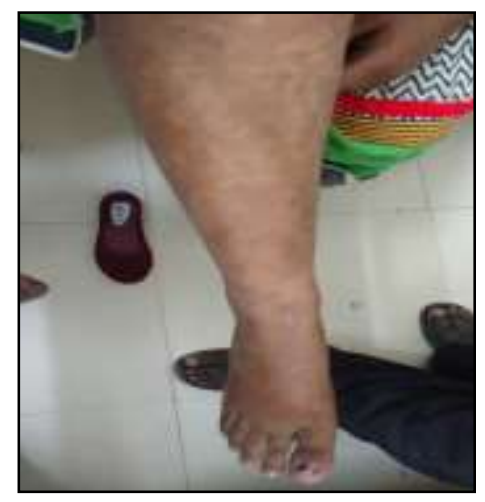

AT

Case $3^{\text {rd }}$
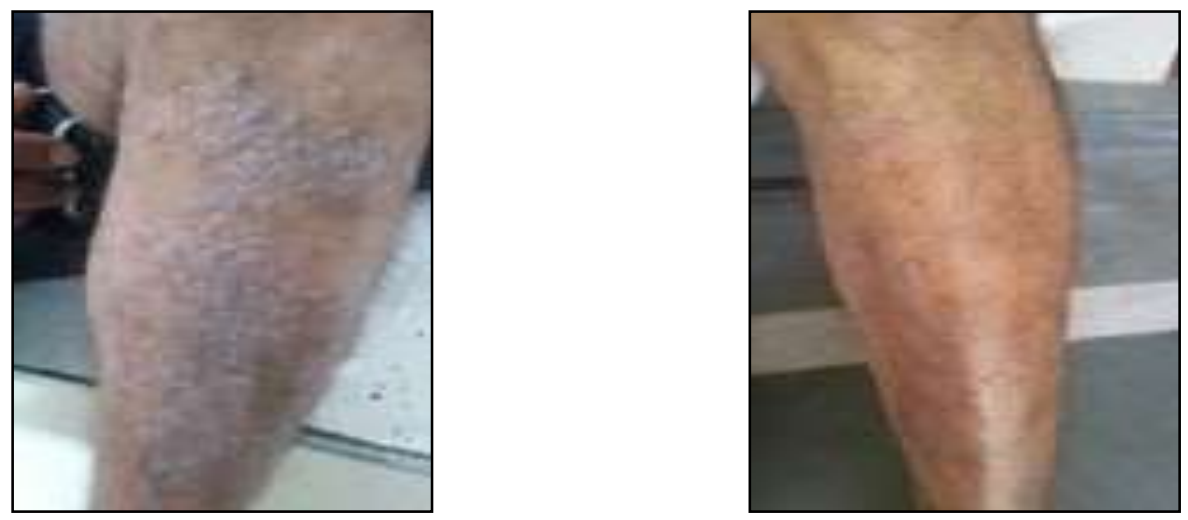